\title{
Modified Dietetic Skim And Cotton Sheet Oil Dan Susu Formula 75 Terhadap Berat Badan Anak Balita Gizi Kurang
}

\author{
Pembronia Nona Fembi ${ }^{1}$, Yosefina Nelista ${ }^{2}$ \\ Fakultas Ilmu-Ilmu Kesehatan, Universitas Nusa Nipa Maumere ${ }^{1,2}$ \\ E-mail: ${ }^{1}$ fembipembronia9@gmail.com
}

\begin{abstract}
Children under five are a group that is prone to malnutrition because they are still experiencing a growth cycle, a development that requires more nutrients than other age groups. The impact of nutritional deficiencies; low body resistance, the body is susceptible to infectious diseases. The purpose of this study was to analyze the effectiveness of giving modified dietetic skim and cotton sheet oil (MODISCO) and Formula-75 milk to increase body weight of malnourished children in Puskesmas Waigete, Sikka Regency. The type of research used is Quasy experimental pretest and posttest design. The population of this research was 181 underweight children with malnutrition. The sampling technique used purposive sampling. The sample of this study was 24 underweight children with malnutrition, divided into 2 (two), namely group A was given MODISCO intervention and group B was given Formula-75 milk. The intervention was given once a day for 1 month at a dose of $150 \mathrm{kcal} / \mathrm{kgbb} /$ day for MODISCO and $1000 \mathrm{ml}$ per day for 75 formula milk. Data analysis used Paired t-Test and Independent Samples Test. Paired T-Test analysis, groups A and B obtained P-value (0.000) <0.05, it was concluded that there was an increase in body weight after being given MODISCO and Formula-75 milk. Based on the analysis of the Independent Samples Test, groups A and B obtained a P-value (0.876)> 0.05, it was concluded that there was no difference in body weight for under-nourished toddlers who were given MODISCO and Formula-75 milk. There is no difference in body weight of malnourished underweight children in group A and group B, so it is concluded that MODISCO and Formula-75 milk can increase the weight of malnourished children underweight. The results of this study are an additional intervention to increase the weight of children under malnutrition.
\end{abstract}

Keywords: Children; Toddler; Malnutrition; MODISCO;Formula-75 Milk.

\begin{abstract}
ABSTRAK
Anak Balita merupakan kelompok yang mudah mengalami kekurangan gizi sebab masih mengalami siklus pertumbuhan, perkembangan yang membutuhkan zat gizi yang lebih dari kelompok umur lain. Dampak dari kekurangan gizi;daya tahan tubuh rendah, tubuh mudah terserang penyakit infeksi. Tujuan penelitian ini menganalisis efektivitas pemberian modified dietetic skim and cotton sheet oil (MODISCO) dan susu Formula-75 terhadap peningkatan berat badan anak BALITA gizi kurang di puskesmas Waigete Kabupaten Sikka. Jenis penelitian yang digunakan Quasy experiment pretest and posttest design. Populasi penelitian ini anak BALITA gizi kurang sebanyak 181 orang.Teknik pengambilan sampel menggunakan purposive sampling. Sampel penelitian ini anak BALITA gizi kurang sebanyak 24 orang, dibagi 2 (dua) yaitu kelompok A diberikan intervensi MODISCO dan Kelompok B diberikan Susu Formula-75.Intervensi diberikan sehari sekali selama 1 bulan dengan takaran $150 \mathrm{kkal} / \mathrm{kgbb} /$ hari untuk MODISCO dan $1000 \mathrm{ml}$ perhari untuk susu Formula 75. Analisis data menggunakan Paired t - Test dan Independent Samples Test. Analisis Paired T-Test, kelompok A dan B didapatkan nilai $\mathrm{P}_{\text {-value }}(0.000)<0.05$, disimpulkan ada peningkatan berat badan setelah diberikan MODISCO dan susu Formula-75. Berdasarkan analisis Independent Samples Test, kelompok A dan B didapatkan P-value $(0.876)>0.05$, disimpulkan tidak ada perbedaan berat badan BALITA gizi kurang yang diberi MODISCO dan susu Formula-75. Tidak terdapat perbedaan berat badan anak BALITA gizi kurang pada kelompok A dan kelompok B, sehingga disimpulkan bahwa MODISCO dan Susu Formula-75 dapat meningkatkan berat badan anak BALITA gizi kurang. Hasil penelitian ini menjadi intervensi tambahan untuk meningkatkan berat badan anak BALITA gizi kurang.
\end{abstract}

Kata kunci : Anak BALITA; Gizi Kurang; MODISCO; Susu Formula-75. 

Vol. 16 No. 3 September - Desember 2021

\section{PENDAHULUAN}

Permasalahan gizi terjadi disetiap siklus kehidupan, umumnya terjadi pada balita, karena anak umur balita mengalami pertumbuhan paling cepat daripada anak umur lainnya sehingga kebutuhan gizi lebih banyak dibutuhkan untuk pertumbuhan dan perkembangan. Perkembangan kemampuan berbahasa, kreativitas, kesadaran sosial, emosional, dan intelegensia berjalan sangat cepat dan menjadi landasan perkembangan berikutnya. Asupan zat gizi mempunyai pengaruh besar terhadap perkembangan anak dari bayi hingga masa remaja. Diet seimbang tidak hanya berpengaruh terhadap pertumbuhan, tetapi juga berfungsi sebagai imunitas, penunjang kemampuan intelektual ${ }^{(1,2)}$. Prevalensi di Indonesia berdasarkan hasil Pemantauan Status Gizi (PSG) balita 0-59 bulan yang mengalami masalah gizi berdasarkan indeks Berat Badan menurut Umur (BB/U)secara Nasional yaitu $17,8 \%$ yang terdiri dari gizi kurang $14,0 \%$. Untuk wilayah provinsi prevalensi gizi kurang terbanyak yaitu Provinsi NTT 20,9\% diatas standar Nasional dan yang paling terendah adalah Provinsi Bali 6,6\%. ${ }^{(2)}$.Berdasarkan hasil Pemantauan Status Gizi (PSG) tahun 2017, yang diukur melalui indeks BB/U, diperoleh data bahwa NTT menduduki peringkat pertama untuk status gizi kurang yaitu sebesar $16 \%$. Hal ini menunjukan bahwa status gizi kurang di NTT sudah melebihi standar nasional menurut PSG yaitu 11,3\%.(3). Studi pendahuluan yang dilakukan di Kabupaten Sikka menunjukan bahwa kejadian gizi kurang total di Kabupaten Sikka pada tahun 2017 sebanyak 2.258 BALITA, Tahun 2018 sebanyak 1.559 BALITA, pada tahun 2019 sebanyak 2.475 BALITA. Puskesmas Waigete merupakan salah satu Puskesmas yang mempunyai cakupan BALITA gizi kurang terbanyak, yakni pada tahun pada tahun 2018 sebanyak 120 BALITA sedangkan pada tahun 2019 mengalami peningkatan menjadi 181 BALITA yang mengalami gizi kurang. ${ }^{(4)}$.

Dampak yang ditimbulkan dari kekurangan gizi yaitu daya tahan tubuh rendah sehingga tubuh mudah terserang penyakit infeksi, kekurangan energi dan protein yang menyebabkan tumbuh kembang balita terganggu, serta berbagai macam penyakit lain. ${ }^{(5)}$.Timbulnya masalah gizi adalah multifaktor, oleh karena itu penanganannya harus melibatkan berbagai sektor terkait. Upaya yang akan dilakukan dalam penanganan gizi buruk yaitu Modified Dietetic Skim and Cotton Sheet Oil (MODISCO) dan susu formula F-75. ${ }^{(6)}$.

Upaya yang dilakukan oleh pihak Puskesmas Waigete beserta kader posyandu melakukan penyuluhan dan pemberian biskuit PMT dan MP-
ASI. Dari Puskesmas dan Posyandu belum melakukan pemberian MODISCO (Modified Dietetic Skim and Cotton Sheet Oil) dan pemberian susu Formula-75. Berdasarkan pada pengamatan terhadap fenomena yang ada dan beberapa referensi yang telah diuraikan, maka dipandang perlu untuk melakukan penelitian dengan pemberian Modified Dietetic Skim and Cotton Sheet Oil (MODISCO) dan susu formula F-75 kepada balita gizi buruk dengan harapan dapat memperbaiki status gizi balita.Tujuan penelitian ini adalah menganalisis efektivitas pemberian modified dietetic skim and cotton sheet oil (MODISCO) dan susu formula F-75 terhadap peningkatan berat badan balita gizi kurang di puskesmas Waigete Kabupaten Sikka.

\section{METODE}

Penelitian ini merupakan jenis penelitian Quasy Experiment. Penelitian terdiri dari dua kelompok perlakuan eksperimen yaitu : kelompok perlakuan A menggunakan pemberian Modified Dietetic Skim And Cotton Sheet Oil (MODISCO), kelompok perlakuan B menggunakan pemberian susu formula F-75. Desain yang digunakan dalam penelitian ini adalah : pretest and posttest design with two comparison treatmens. ${ }^{(7)}$. Populasi dalam penelitian ini adalah BALITA gizi kurang di Wilayah kerja Puskesmas Waigete sebanyak 181 orang. Sampel dalam penelitian ini adalah BALITA gizi kurang sejumlah 24 orang yang memenuhi kriteria inklusi dan kriteria eksklusi, yang dibagi dalam 2 (dua) kelompok yaitu kelompok A mendapat intervensi MODISCO dan Kelompok B mendapat intervensi susu Formula 75. Masing masing kelompok terdiri dari 12 orang BALITA gizi kurang. Penelitian ini dilaksanakan pada tanggal 06 Agustus - 07 September 2020. Proses pengumpulan data melalui 3 (tiga) tahap yaitu; a) Pre test sebelum diberikan intervensi pemberian modified dietetic skim and cotton sheet oil (MODISCO) dan susu formula F-75 dilakukan pengukuran berat badan balita gizi kurang, setelah itu anak BALITA yang memenuhi kriteria inklusi dan ekslusi dibagi menjadi 2 (dua) yaitu kelompok A diberikan intervensi MODISCO dan Kelompok B diberikan Susu Formula-75, b) Intervensi yaitu pemberian modified dietetic skim and cotton sheet oil (MODISCO) pada kelompok A dan susu formula F75 pada kelompok $\mathrm{B}$, intervensi diberikan sehari sekali dengan takaran $150 \mathrm{kkal} / \mathrm{kgbb} / \mathrm{hari}$ untuk MODISCO dan $1000 \mathrm{ml}$ perhari untuk susu Formula 75 selama 1 bulan, c) Post test yaitu dilakukan pada hari ke hari terakhir setelah intervensi, peneliti kembali melakukan pengukuran berat badan pada kelompok A dan pada kelompok B. 


\section{HASIL}

\section{Tabel 1}

Distribusi frekuensi BALITA gizi kurangberdasarkan usia di Puskesmas Waigete $(\mathrm{n}=24)$

\begin{tabular}{l|l|l|l|l}
\hline \multirow{2}{*}{$\begin{array}{l}\text { Kategori } \\
\text { Umur }\end{array}$} & \multicolumn{2}{l|}{$\begin{array}{l}\text { Kel A } \\
\text { Modisco }\end{array}$} & \multicolumn{2}{l}{$\begin{array}{l}\text { Kel B } \\
\text { Susu Formula 75 }\end{array}$} \\
\cline { 2 - 5 } & $\mathrm{n}$ & $\%$ & $\mathrm{n}$ & $\%$ \\
\hline $0-24$ bln & 5 & 41.7 & 1 & 8.3 \\
\hline $24-34$ bln & 7 & 58.3 & 4 & 33.3 \\
\hline $36-60$ bln & 0 & 0 & 7 & 58.3 \\
\hline
\end{tabular}

Sumber : Data primer, Agustus 2020

Berdasarkan Tabel 1. dapat dijelaskan bahwa usia BALITA gizi kurang pada kelompok A (MODISCO) paling banyak pada usia 24-34 bulan sebesar 7 $(58,3 \%)$ dari 12 anak BALITA gizi kurang dan kelompok B (susu Formula 75) paling banyak pada usia 36-60 bulan sebesar 7 (58.3) dari 12 anak BALITA gizi kurang.

Tabel 2

Distribusi frekuensi BALITA gizi kurang berdasarkan jenis kelamin di Puskesmas Waigete (n $=24$ )

\begin{tabular}{|c|c|c|c|c|}
\hline \multirow{2}{*}{$\begin{array}{l}\text { Kategori } \\
\text { Jenis } \\
\text { Kelamin }\end{array}$} & \multicolumn{2}{|c|}{$\begin{array}{l}\text { KEL A } \\
\text { MODISCO }\end{array}$} & \multicolumn{2}{|c|}{$\begin{array}{l}\text { KEL B } \\
\text { Susu Formula } 75\end{array}$} \\
\hline & $\mathrm{n}$ & $\%$ & $\mathrm{n}$ & $\%$ \\
\hline Laki-Laki & 6 & 50 & 6 & 50 \\
\hline Perempuan & 6 & 50 & 6 & 50 \\
\hline
\end{tabular}

Sumber : Data primer, Agustus 2020

Berdasarkan Tabel 2. dapat dijelaskan bahwa jenis kelamin BALITA gizi kurang pada kelompok A (MODISCO) dan kelompok B (susu Formula 75) sama rata yaitu jenis kelamin laki laki dan perempuan masing masing berjumlah $6(50 \%)$ anak BALITA gizi kurang.

\section{Tabel 3}

Distribusi frekuensi umur ibu BALITA gizi kurang di Puskesmas Waigete $(\mathrm{n}=24)$

\begin{tabular}{l|l|l|l|l}
\hline \multirow{2}{*}{$\begin{array}{l}\text { Kategori } \\
\text { Umur Ibu }\end{array}$} & \multicolumn{2}{l|}{ KEL A } & \multicolumn{2}{l}{ KEL B } \\
& \multicolumn{2}{l}{ MODISCO } & \multicolumn{2}{l}{ Susu Formula 75 } \\
\cline { 2 - 5 } & n & \% & n & \% \\
\hline$<25$ thn & 1 & 8.3 & 3 & 25 \\
\hline $25-35$ thn & 8 & 66.7 & 5 & 41.7 \\
\hline$>35$ thn & 3 & 25 & 4 & 33.3 \\
\hline
\end{tabular}

Sumber : Data primer, Agustus 2020

Berdasarkan Tabel 3. dapat dijelaskan bahwa umur ibu BALITA gizi kurang pada kelompok A (MODISCO) paling banyak pada usia 25-35 tahun sebesar 8 $(66,7 \%)$ dari 12 ibu BALITA gizi kurang dan kelompok B (susu Formula 75) paling banyak pada usia 25-35 tahun sebanyak 5 (41.7\%) dari $12 \mathrm{ibu}$ BALITA gizi kurang.

\section{Tabel 4}

Distribusi frekuensi pekerjaan ibu BALITA gizi kurang di Puskesmas Waigete $(\mathrm{n}=24)$

\begin{tabular}{l|l|c|l|l}
\hline $\begin{array}{l}\text { Kategori } \\
\text { Umur } \\
\text { Ibu }\end{array}$ & \multicolumn{2}{l|}{$\begin{array}{l}\text { Kelompok A } \\
\text { (MODISCO) }\end{array}$} & $\begin{array}{l}\text { Kelompok B } \\
\text { (Susu Formula } \\
\mathbf{7 5 )}\end{array}$ \\
\cline { 2 - 5 } & $\mathbf{n}$ & $\mathbf{\%}$ & $\mathbf{n}$ & $\mathbf{\%}$ \\
\hline IRT & 6 & 50 & 7 & 58.3 \\
\hline Petani & 6 & 50 & 5 & 41.7 \\
\hline
\end{tabular}

Berdasarkan Tabel 4. dapat dijelaskan bahwa pekerjaan ibu BALITA gizi kurang pada kelompok A (MODISCO) sama rata antara IRT dan petani yaitu masing masing $6(50 \% \%)$ dari 12 ibu BALITA gizi kurang dan kelompok B (susu Formula 75) paling banyak IRT sebanyak 7 (58.3\%) dari 12 ibu BALITA gizi kurang.

\section{Tabel 5}

Perbedaan rata-rata berat badan BALITA gizi kurang sebelum dan setelah diberikan intervensi MODISCO dan Susu Formula 75 di Puskemas Waigete

\begin{tabular}{|c|c|c|c|c|c|}
\hline \multicolumn{3}{|c|}{$\begin{array}{l}\text { Kelompok A } \\
\text { (MODISCO }\end{array}$} & \multicolumn{3}{|c|}{$\begin{array}{l}\text { Kelompok B } \\
\text { (Susu Formula 75) }\end{array}$} \\
\hline $\begin{array}{l}\text { BB } \\
\text { (kg) } \\
\text { (pre) }\end{array}$ & $\begin{array}{l}\mathrm{BB}(\mathrm{k} \\
\mathrm{g}) \\
\text { (post } \\
\text { ) }\end{array}$ & $\begin{array}{l}\text { Selisi } \\
\mathrm{h}\end{array}$ & $\begin{array}{c}\text { BB } \\
(\mathrm{kg}) \\
(\mathrm{pre})\end{array}$ & $\begin{array}{l}\text { BB } \\
(\mathrm{kg}) \\
\text { (post }\end{array}$ & Selisih \\
\hline 11.4 & 12.2 & 0.8 & 11.0 & 11.8 & 0.8 \\
\hline 12.4 & 13.2 & 0.8 & 12.6 & 13.5 & 0.9 \\
\hline 7.6 & 8.1 & 0.5 & 12.5 & 13.3 & 0.8 \\
\hline 12.2 & 12.7 & 0.5 & 9.8 & 10.8 & 1 \\
\hline 11.8 & 12.6 & 0.8 & 10.1 & 11.0 & 0.9 \\
\hline 10.2 & 10.7 & 0.5 & 9.8 & 10.9 & 1.1 \\
\hline 11.5 & 12.5 & 1 & 12.1 & 13.0 & 0.9 \\
\hline 11.4 & 12 & 0.6 & 13.2 & 14.7 & 1.5 \\
\hline 7.7 & 8.1 & 0.4 & 10.8 & 11.2 & 0.4 \\
\hline 10.2 & 11 & 0.8 & 10.5 & 11.0 & 0.5 \\
\hline 13.3 & 14.4 & 1.1 & 7.5 & 8.6 & 1.1 \\
\hline 13 & 14.4 & 1.4 & 12.1 & 12.7 & 0.6 \\
\hline $\begin{array}{c}11.0 \\
5\end{array}$ & 11.75 & & 11.0 & 11.8 & \\
\hline
\end{tabular}

Sumber : Data primer, Agustus 2020 
Berdasarkan tabel 5 dapat dijelaskan bahwa hasil penelitian diperoleh rata rata berat badan BALITA gizi kurang pada pada kelompok A (MODISCO) pre test adalah 11.05 setelah intervensi menjadi 11.75 sedangkan pada kelompok B (susu Formula-75 yaitu diperoleh nilai rata rata pre test adalah 11.00 dan post test menjadi 11.87. Hal ini dapat disimpulkan bahwa dari kedua intervensi yaitu MODISCO dan Susu Formula -75 dapat meningkatkan berat badan BALITA gizi kurang.

\section{Tabel 6}

Hasil Uji Statistik Paired T-Test pemberian Modified Dietetic Skim and Cotton Sheet Oil (MODISCO) dan susu Formula 75 terhadap peningkatan berat badan BALITA gizi kurang di puskesmas Waigete Kabupaten Sikka

\begin{tabular}{c|l|l|l|l|l|l|}
\hline KEL & $\begin{array}{l}\text { Mea } \\
\text { n } \\
\text { pre }\end{array}$ & $\begin{array}{l}\text { Mean } \\
\text { post }\end{array}$ & $\mathbf{C}$ & $\begin{array}{l}\text { T } \\
\text { hitung }\end{array}$ & $\begin{array}{l}\text { T } \\
\text { tabel }\end{array}$ & $\begin{array}{l}\text { P- } \\
\text { Value }\end{array}$ \\
\hline A & $\begin{array}{l}11.0 \\
5\end{array}$ & 11.75 & $\begin{array}{l}0.99 \\
7\end{array}$ & $\begin{array}{l}12.12 \\
4\end{array}$ & $\begin{array}{l}1.79 \\
5\end{array}$ & $\begin{array}{l}0.00 \\
0\end{array}$ \\
\hline B & $\begin{array}{l}11.0 \\
0\end{array}$ & 11.87 & $\begin{array}{l}0.98 \\
4\end{array}$ & $\begin{array}{l}10.98 \\
4\end{array}$ & $\begin{array}{l}1.79 \\
5\end{array}$ & $\begin{array}{l}0.00 \\
0\end{array}$ \\
\hline
\end{tabular}

Sumber : Data primer, Agustus 2020

Berdasarkan tabel 6 dapat dijelaskan bahwa pada kelompok A (MODISCO), nilai rata-rata pre test sebesar 11.05, sedangkan nilai rata-rata post test sebesar 11.75. Dari nilai korelasi sebesar 0.997 dengan signifikansi 0.000 . Hal ini berarti terjadi hubungan yang sangat kuat antara nilai sebelum dan setelah diberikan intervensi MODISCO karena nilai mendekati 1. Karena nilai $\mathrm{T}$ hitung $>\mathrm{T}$ tabel (12.124>1.795) , maka Ho ditolak, Ha diterima. Jadi dapat disimpulkan bahwa ada perbedaan rata-rata nilai pre test sebelum dan setelah diberikan intervensi MODISCO.

Berdasarkan tabel 6 dapat dijelaskan bahwa pada kelompok B (Susu Formula-75), nilai rata-rata pre test sebesar 11.00, sedangkan nilai rata-rata post test sebesar 11.87. Dari nilai korelasi sebesar 0.984 dengan signifikansi 0.000 . Hal ini berarti terjadi hubungan yang sangat kuat antara nilai sebelum dan setelah diberikan intervensi susu Formula-75, karena nilai mendekati 1 . Karena nilai $-t$ hitung >tabel (10.247>1.795) , maka Ho ditolak, Ha diterima. Jadi dapat disimpulkan bahwa ada perbedaan rata-rata nilai pre test sebelum dan setelah diberikan intervensi susu Formula-75.

Berdasarkan tabel 7 dapat dijelaskan bahwa berdasarkan hasil analisis Independent Samples Test pada kelompok A (MODISCO), nilai rata-rata sebesar 11.75, sedangkan nilai rata-rata pada kelompok B (Susu Formula-75) sebesar 11.87. Karena nilai $\mathrm{t}$ hitung < t tabel $(0.158<1.812)$, maka Ho diterima Ha ditolak. Jadi dapat disimpulkan bahwa tidak ada perbedaan rata-rata berat badan BALITA gizi kurang yang diberi intervensi MODISCO dan intervensi susu Formula-75.

\section{Tabel 7}

Hasil Analisis Uji Independent Samples Test Perbedaan Pemberian Modified Dietetic Skim and Cotton Sheet Oil (MODISCO) dan susu Formula 75 terhadap peningkatan berat badan BALITA gizi kurang di puskesmas Waigete Kabupaten Sikka

\begin{tabular}{l|l|l|l|l}
\hline KEL & Mean & T hitung & T tabel & $\mathbf{P}_{\text {value }}$ \\
\hline $\mathrm{A}$ & 11.75 & 0.158 & 1.812 & 0.876 \\
\cline { 1 - 2 } $\mathrm{B}$ & 11.87 & & & \\
\hline
\end{tabular}

Sumber : Data primer, Agustus 2020

\section{AlembahASAN}

a Hasil penelitian membuktikan bahwa pada kelompok A (MODISCO), nilai rata-rata pre test sebesar 11.05, sedangkan nilai rata-rata post test sebesar 11.7 sedangkan hasil uji paired $\mathrm{t}$ test didapatkan nilai $\mathrm{P}_{\text {-value }}(0.000)<0.05$, dan nilai $\mathrm{T}$ loitong > $\mathrm{T}$ tabel (12.124>1.795), yang dapat disimpulkan bahwa ada perbedaan rata-rata nilai pre test sebelum dan setelah diberikan intervensi MODISCO. Berdasarkan pada hasil tersebut tampak setelah pemberian MODISCO sehari sekali selama 1 bulan dengan takaran $150 \mathrm{kkal} / \mathrm{kgbb} / \mathrm{hari}$ pada kelompok A terjadi peningkatan berat badan anak balita. Menurut Adi A.C (2019), MODISCO memiliki kalori yang tinggi yaitu 100 kalori/ $100 \mathrm{cc}$. Dengan pemberian MODISCO dapat meningkatkan berat badan anak sebanyak $30-100$ gr dalam sehari. ${ }^{(8)}$.MODISCO baik di berikan kepada balita yang mengalami status gizi kurang, pada masa penyembuhan. Berdasarkan hasil dari beberapa penelitian MODISCO tidak memberikan dampak yang buruk terhadap kesehatan anak akan tetapi MODISCO tidak dapat diberikan secara bebas kepada anak yang kelebihan berat badan (obesitas), penderita penyakit ginjal, hati (kuning) dan jantung tanpa konsultasi dokter. ${ }^{(8)}$. Cara pemberian 
MODISCO berpengaruh terhadap keberhasilan kenaikan status gizi balita. Hal ini sejalan dengan penelitian dari Roedi Irawan, 2016 di RSU dr. Soetomo Surabaya tentang MODISCO yang menyatakan bahwa terdapat perbedaan yang signifikan antara berat badan balita sebelum dan sesudah diberikan MODISCO. ${ }^{(9)}$.Selain itu hasil penelitian dari Kristiyanto (2006), menyatakan MODISCO tidak berpengaruh pada kenaikan status gizi, hal ini disebabkan oleh faktor lain yang lebih berpengaruh diantaranya status infeksi balita yang dapat menghambat kenaikan status gizi. ${ }^{(10)}$. Faktor pemberian MODISCO adalah yang paling berpengaruh terhadap kenaikkan status gizi balita (> -2SD) dan pemberian MODISCO 4 kali lebih berpengaruh terhadap kenaikan status gizi balita. Besarnya pengaruh pemberian MODISCO terhadap keberhasilan kenaikan status gizi balita dinilai dari

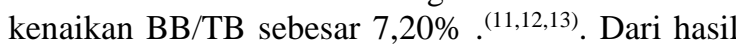
penelitian ini Pemberian MODISCO bermanfaat untuk memenuhi kebutuhan zat gizi anak. Selain MODISCO anak juga tetap diberikan makanan keluarga sehari hari namun hal ini akan menjadi masalah apabila anak kurang nafsu makan. Oleh karena itu teknik pengolahan dan penyajian makanan juga sangat berpengaruh terhadap nafsu makan anak. Ibu harus mampu memberikan tampilan yang menarik perhatian anak.

Pada kelompok B (Susu Formula-75), hasil penelitian membuktikan bahwa, nilai rata-rata pre test sebesar 11.00, sedangkan nilai rata-rata post test sebesar 11.87, sedangkan hasil uji paired t test didapatkan nilai $\mathrm{P}_{\text {-value }}(0.000)<0.05$ dan nilai t-hitung $>$ t-tabel (10.247>1.795), maka Ho ditolak, Ha diterima. Jadi dapat disimpulkan bahwa ada perbedaan rata-rata nilai pre test sebelum dan setelah diberikan intervensi susu Formula-75. Berdasarkan pada hasil tersebut tampak setelah pemberian susu formula 75 yang diberikan sekali sehari dengan takaran $1000 \mathrm{ml}$ perhari selama 1 bulan pada kelompok B terjadi peningkatan berat badan anak balita. Susu formula 75 adalah makanan cair yang mengandung 25 gram susu bubuk skim, 100 gram gula pasir, 30 gram minyak sayur dan $20 \mathrm{ml}$ larutan elektrolit dalam larutan 1000 ml. ${ }^{(6)}$. Kandungan Gizi Formula 75 yaitu 750 kal kalori, 9 gr Protein, 13 gr laktosa, 36 mmol kalium, 6 mmol natrium, 4,3 mmol magnesium, $20 \mathrm{mg}$ seng, dan 2,5 mg tembaga dan Formula 75 merupakan makanan cair yang mengandung tinggi kalori, protein dan cukup vitamin-mineral serta mudah untuk diserap. ${ }^{(14)}$. Hal ini sejalan dengan penelitian Ningrum, P, Nyna (2017) dan Penelitian Sulistiawati (2011), tentang susu formula 75 yang menyatakan bahwa ada peningkatan berat badan anak balita gizi kurang setelah diberikan susu formula $75^{(15,16)}$.Susu formula 75 diberikan dengan tujuan mengejar ketinggalan berat badan yang pernah dialami, mencapai berat badan normal sesuai dengan panjang badan serta agar tahap perkembangan kepandaian dan motoriknya sesuai umurnya. ${ }^{(15,16)}$.
Berdasarkan analisis Independent Samples Test, kelompok A dan $\mathrm{B}$ didapatkan $\mathrm{P}$-value (0.876) $>0.05$, disimpulkan tidak ada perbedaan berat badan BALITA gizi kurang yang diberi MODISCO dan susu Formula-75. Berdasarkan pada hasil tersebut tampak terbukti bahwa MODISCO dan Susu Formula75 dapat meningkatkan berat badan anak BALITA gizi kurang. Rerata kenaikan berat badan balita antara sebelum dan setelah diberikan susu MODISCO adalah 750 gram sedangkan rerata kenaikan berat badan antara sebelum dan setelah diberikan susu formula 75 adalah 800 gram. Evaluasi berat badan balita gizi buruk dinyatakan intervensi berhasil jika terdapat kenaikan berat badan $\geq \quad 50$ gram/KgBB/minggu ${ }^{(17,18,19)}$. Berdasarkan hasil penelitian diatas bahwa intervensi MODISCO dan susu formula 75 dilakukan dalam jangka waktu 1 bulan dengan kenaikan berat badan rata-rata 750 sampai dengan 800 gram. Sehingga dapat diartikan bahwa setiap minggu ada kenaikan sebesar 187,5 sampai 200 gram/KgBB/minggu maka MODISCO dan susu formula 75 dapat meningkatkan berat badan balita gizi kurang sesuai standar yang diharapkan oleh Depkes.

\section{KESIMPULAN}

Hasil penelitian menjawab tujuan penelitian bahwa Ada peningkatan berat badan setelah diberikan intervensi MODISCO dan Susu Formula 75, MODISCO dan Susu Formula-75 dapat meningkatkan berat badan anak BALITA gizi kurang. Berdasarkan hasil penelitian ini dapat diberikan beberapa rekomendasi sebagai berikut; Bagi pihak puskesmas, kader posyandu, para orang tua hasil penelitian ini dapat menjadi intervensi tambahan untuk meningkatkan berat badan anak BALITA gizi kurang; bagi para orang tua agar memperhatikan teknik pengolahan dan penyajian makanan karena sangat berpengaruh terhadap nafsu makan anak, sehingga memberikan tampilan yang menarik perhatian anak.

\section{UCAPAN TERIMA KASIH}

Penulis mengucapkan terima kasih kepada pihak-pihak yang telah membantu menyelesaikan kegiatan penelitian dan penulisan artikel ini, khususnya kepada Kemenristekdikti dan Lembaga Penelitian dan Pengabdian Kepada Masyarakat Universitas Nusa Nipa yang telah memberikan izin dan memfasilitasi pelaksanaan kegiatan ini. Ucapan terima kasih juga ditujukan kepada Balita dan Ibu Balita Gizi Kurang yang bersedia berpartisipasi dalam kegiatan penelitian ini.

\section{DAFTAR PUSTAKA}

1. Hardinsyah RH, Napitupulu V. Kecukupan energi, protein, lemak dan karbohidrat. Widya Karya Nasional Pangan dan Gizi. Jakarta. 2012. 
2. Hardiansyah M, Supariasa I. Ilmu gizi teori dan aplikasi (Nutrition theory and application). Jakarta: PT Raja Grafindo Persada. 2017.

3. Kemenkes RI. Hasil Pemantauan Status Gizi (PSG) Tahun 2016. Jakarta: Direktorat Gizi Masyarakat Direktorat Jendral Kesehatan Masyarakat Kemenkes.2017.

4. Profil Dinas Kesehatan Kabupaten Sikka Nusa Tenggara Timur. 2019.

5. Rusilanti MD, Yulianti Y. Gizi dan kesehatan anak prasekolah. Bandung: Remaja Rosdakarya. 2015.

6. Depkes RI. Petunjuk Teknis Tatalaksana Anak Gizi Buruk Buku II. Jakarta: Departemen Kesehatan Republik Indonesia. 2011.

7. Dharma KK. Metodologi penelitian keperawatan: Panduan melaksanakan dan menerapkan hasil penelitian. 2011.

8. Adi AC. Makanan Penambah Berat Badan Anak.2019.

9. Irawan R. Perbedaan Kecepatan Kesembuhan Anak Gizi Buruk yang Diberi Modisco Susu Formula dan Modisco Susu Formula Elemental Di RSU dr. Soetomo Surabaya. Sari Pediatri. 2016 Dec 5;8(3):226-30.

10. Kristiyanto K. Hubungan Tingkat Pendidikan Ibu, Pengetahuan Gizi, Pendapatan Keluarga Dan Konsumsi Kalori Dengan Status Gizi Balita Di Puskesmas Beji Kecamatan Junrejo Batu (Doctoral dissertation, University of Muhammadiyah Malang).2006.

11. Kementrian Kesehatan RI,. Pedoman Pelayanan Anak Gizi Buruk, Dirjen Pembinaan Kesehatan Masyarakat, Direktorat Bina Gizi Masyarakat, Jakarta. 2011.

12. Kemenkes RI. Standar Antropometri Penilaian Status Gizi Anak. Jakarta: Direktorat Bina Gizi.2011.

13. Kemenkes RI. Situasi dan Analisis Gizi. Pusat Data dan Informasi. Jakarta.2015.

14. Petunjuk Teknis Tata Laksana Gizi Buruk.Buku I.Depertemen Kesehatan RI.2011.

15. Ningrum NP. Pengaruh Pemberian F75 Terhadap Kenaikan Berat Badan Balita Dengan Gizi Kurang Di Desa Tambak Cemandi Kecamatan Sedati Sidoarjo. EMBRIO. 2017 Nov 28;9:24-8.

16. Sulistiyawati S, Rustina Y, Hastono SP. Pemberian Diet Formula 75 Dan 100 Meningkatkan Berat Badan Balita Gizi Buruk Rawat Jalan. Jurnal Keperawatan Indonesia. 2012 Nov 24;15(3):159-64.

17. Depkes RI, Pedoman Strategi KIE Keluarga Sadar Gizi (KADARZI). Direktorat Jendral Bina Kesehatan Masyarakat. Direktorat Bina Gizi Masyarakat. Jakarta. 2007.
18. Depkes RI,.Pedoman Pendampingan Keluarga Menuju Kadarzi. Direktorat Jendral Bina Kesehatan Masyarakat. Jakarta. 2007.

19. Depkes RI,. Pedoman Operasional Keluarga Sadar Gizi Di Desa Siaga. Direktorat Jendral Bina Kesehatan Masyarakat. Direktorat Bina Gizi Masyarakat. Jakarta. 2007. 